\title{
A retórica na Antiguidade e na Idade Média
}

\author{
Ricardo da Costa ${ }^{1}$
}

Resumo: $\mathrm{O}$ artigo trata da retórica na Antiguidade e na Idade Média a partir da perspectiva de onze filósofos - Platão e Aristóteles, Cícero, Sêneca e Quintiliano, a Retórica a Herênio (de autor desconhecido), Agostinho, Marciano Capela e Isidoro de Sevilha, Bernardo de Claraval e Ramon Llull. Oferece, ainda, um extrato por nós traduzido da Retórica nova (1301) do filósofo cataláo, a primeira tradução para a língua portuguesa.

Palavras-Chave: Retórica. Filosofia clássica. Filosofia Medieval. Discurso.

\section{A retórica na Grécia antiga}

\section{Imagem 1}

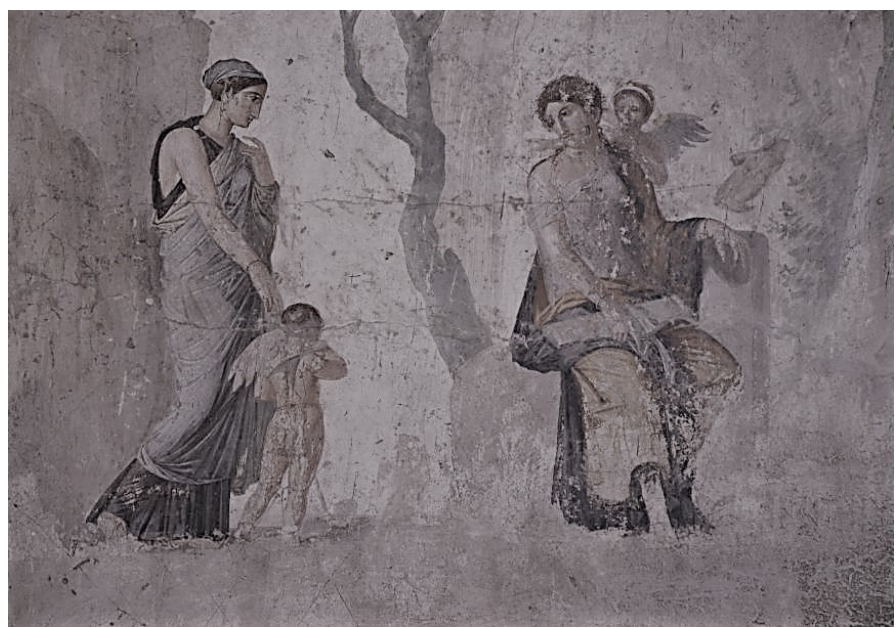

Afresco (séc. I), $154 \times 116$ cm, Museu Arqueológico Nacional de Nápoles (inv. n. 9257). Pompéia, Sala LXXI, Casa do amor punido. Foto: Carole Raddato (public domain).

${ }_{1}^{1}$ Professor Titular da Universidade Federal do Espírito Santo (UFES), Vitória, ES - Brasil. (D) https:// orcid.org/0000-0002-1817-9091 E-mail: ricardocosta1962.rdc@gmail.com

http://dx.doi.org/10.1590/0101-3173.2019.v42esp.18.p353

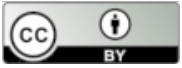

This is an open-access article distributed under the terms of the Creative Commons Attribution License. 
Na história da civilizaçáo ocidental, do ponto de vista da formação do cidadão, a retórica ocupa um lugar especial. Desde cedo, se fez necessário organizar mental e racionalmente os temas políticos em prol do debate e da promoção da coisa pública (res publica). O interesse por esse assunto nasceu na Antiguidade, no seio das cidades-estados gregas. A tradição localizou historicamente sua gênese no séc. V a.C. No entanto, como em praticamente todas as culturas pré-industriais, se pensava em termos transcendentais. Por isso, como tudo na existência humana, a retórica foi uma "dádiva dos deuses". Tudo fora dado à humanidade por uma generosidade divina!

Assim pensavam os antigos: tudo tinha causa na divindade, tudo fora causado por desejo divino, por um ato de amor. Em relação à retórica, sua "deusa criadora” foi Peitho, personificação da persuasão e da sedução. Essa deusa estava no âmbito amoroso de Afrodite e de Eros. Por exemplo, em um afresco em Pompéia, na Itália, há uma residência que a arqueologia denominou Casa do amor punido (imagem 1). Ali, em um afresco (pintura feita enquanto o material da parede ainda está fresco) em uma das salas, Peitho conduz Eros até Afrodite para que aquele seja penalizado por ter se transformado em Marte para atrair uma mulher. Naquela pintura, Afrodite está acompanhada por Anteros (que é, por sua vez, a personificação do amor correspondido). Ambos aguardam a chegada de Eros para proferirem sua punição. Artisticamente, esse afresco sintetiza o ambiente mitológico que propiciou aos homens a dádiva da retórica: envolta pela seduçáo, pelo amor e por Eros, Peitho necessita de seu poder sedutor para realizar seus propósitos oratórios (de convencimento, e com eloquência e poder lascivo).

A Grécia desenvolveu um fervoroso e constante culto a Afrodite e a Peitho na Acrópole de Atenas. Na obra Descrição da Grécia $(9,35,1)$, o geógrafo Pausânias (c. 115-180) relata que, após a unificação de Atenas, o herói mitológico Teseu criou um culto a Afrodite Pandemos e a Peitho na encosta sul da Acrópole de Atenas. Elas também tinham um santuário e um culto em Sicião, cidade grega localizada no Peloponeso. Assim, como assistente (ou companheira) de Afrodite, Peitho estava intimamente ligada à deusa do amor e da beleza. Muitos artistas e poetas exploraram essa íntima conexão, algo ainda mais profundo no contexto do casamento grego antigo, pois os pretendentes tinham que negociar com os pais das jovens para obter sua mão em casamento (e oferecer um preço nupcial por elas). Naturalmente, as mulheres mais desejáveis atraíam mais pretendentes, e a habilidade persuasiva muitas vezes determinava o sucesso da negociação pré-nupcial. A retórica se fazia assim importante nas questóes do amor... 


\section{1. Os SOFISTAS}

Isso no universo da mitologia e da vida cotidiana. A história, tradicionalmente, é bem menos poética. Há muito que os historiadores costumam preocupar-se mais com a política e a economia. Por isso, precisaram a localização do nascimento da retórica: a regiáo de Siracusa, na ilha da Sicília. Seus habitantes gregos, desejosos de recuperar suas terras após a expulsão dos tiranos, sentiram a necessidade de criar discursos racionalmente organizados e persuasivos. A respeito desses siracusanos, costumavam dizer na Antiguidade que eles eram dotados de uma eloquência natural, e que só faltava uma sistematização, um método, para organizar racionalmente esse dom natural de sua cultura nativa.

Córax, discípulo de Empédocles (c. 490-430 a.C.), e Tísias, discípulo de Córax, foram os primeiros mestres a formular a técnica retórica, que consistia basicamente em uma espécie de aconselhamento a respeito do procedimento mais persuasório para apresentar uma causa em uma corte de justiça. Em outras palavras, após descer do Olimpo, nosso tema ganhou o mundo a partir do âmbito jurídico e, aos poucos, conquistou todos e quaisquer espaços sociais (religiosos, cerimoniais, políticos, etc.). Assim, para Córax, a retórica era a arte da persuasão, e de qualquer tema (verdadeiro ou não).

Ainda de acordo com essa tradição, abalizada pela historiografia, a retórica chegou a Atenas com os mestres sofistas Protágoras (c. 490-420 a.C.) e Górgias (c. 485-380 a.C.). Esses sofistas contrapunham a rigidez dos ditados morais tradicionais à possibilidade de defender racionalmente diferentes âmbitos da mesma questão e, com isso, adequar o discurso do retórico conforme cada situação específica para, assim, obter a concordância da plateia. Eram mestres cosmopolitas, viajados, conhecedores de diferentes culturas, que passavam de cidade em cidade sempre prontos a ensinar os alunos a serem bons cidadãos, mas, sobretudo, a serem vitoriosos na política. A qualquer preço. Portanto, a retórica se tornava essencial para a prática político-cidadã da polis.

\section{2. Platão}

Os sofistas foram muito populares entre os estudantes de filosofia. Por exemplo, logo no início da obra Protágoras, Platão (c. 428-348 a.C.) ressalta a fama desse autor e critica Hipócrates (c. 460-370 a.C.) por entregar sua alma aos cuidados daquele sofista, Protágoras, espécie de mercador ou traficante de 
mantimentos espirituais. Por esse motivo exposto por Platão, o problema da moralidade na retórica sempre foi um ponto de vivos e acalorados debates. Desde cedo, Platão criticou os sofistas por suas armadilhas dialéticas, jogos mentais que não conduziam os estudantes necessariamente à verdade, além do fato deles cobrarem por suas aulas, o que, na concepção platônica, desmerecia sua filosofia (vejam que, desde cedo, o sentido positivo do ensino desinteressado, sem qualquer salário, foi posto em discussão, como um valor superior). Por tudo isso, os sofistas, segundo essa tradiçáo socrático-platônica, não assentavam a retórica em um conhecimento autêntico.

Diria mais: a dialética socrática fulminou a dos sofistas! Quem ler os diálogos de Platão confirmará isso. O mais contundente e marcante estudo feito a esse respeito é o do estudioso (e filólogo) alemão Werner Jaeger (1888-1961). Sua obra Paideia é a mais bela defesa da tradição socrático-platônica. Nela, Jaeger defende (sempre com base documental) que Platáo advoga a autêntica retórica como a arte de conduzir as almas por meio da palavra, não apenas nos tribunais e nas reunióes públicas, mas também nos encontros particulares, e sempre com uma aplicação honesta e, por isso, meritória (Fedro, 261b). Para Platão, a retórica é (ou deveria ser) um método rigoroso e verdadeiro de aplicação da dialética, método que, com sua natural benevolência, conseguiria chegar à verdade das coisas (nunca é demais recordar que a dialética era um método argumentativo de pergunta e resposta em um diálogo com pessoas com diferentes pontos de vista para, juntos, descobrirem a verdade do tema debatido).

Não deixa de ser curioso que, sempre em tempos de crise cultural como o nosso, os sofistas ressurjam com força, como se tivessem soberbamente vencido as disputas dialéticas com Sócrates (c. 470-399 a.C.). Nada mais falso! Essa interpretação é típica dos céticos e dos relativistas, povo que abunda hoje na crise contemporânea da educação. Para esses, não é fácil pensar que a retórica - como, aliás, a própria filosofia - estava a serviço da verdade (a primeira) e era (a segunda) a própria ciência da verdade, como disse Aristóteles em sua Metafísica (livro II, 1, 993b19-21), mas também a ideia de bem, pois a retórica procurava aquilo que transmitia a verdade aos objetos cognosciveis (isto é, às coisas possiveis de serem conhecidas) e proporcionava ao sujeito que a conhecia esse poder verdadeiro, esse conhecimento real das essências. $\mathrm{E}$ isso era sumamente belo (A República, livro VI, 508e). 


\section{3. ARIStóteles}

Terminei o parágrafo anterior com Aristóteles (384-322 a.C.) e seu mestre Platão - nosso eterno mestre. O primeiro, discípulo do segundo, proporcionou a primeira sistematização da retórica. Com seu modo realista de analisar as coisas, o filósofo de Estagira é muito claro e direto: a retórica é a outra face da dialética, pois ambas se ocupam de questóes ligadas ao conhecimento e não correspondem a nenhuma ciência específica. Isso porque todas as pessoas tentam, de algum modo, questionar ideias, debater, argumentar, se defender, acusar. Logo, todos, em maior ou menor grau, se valem da retórica.

O leitor contemporâneo, acostumado com todos os tipos de relativismos e matizaçóes, se surpreende de imediato com a firme defesa que o Estagirita faz da importância da verdade e da justiça: "A retórica é útil porque a verdade e a justiça são, por natureza, mais fortes que os seus contrários, e se os juízos não se fizerem como se convém, a verdade e a justiça serão necessariamente vencidas pelos seus contrários, e isso é digno de censura." (ARISTÓTELES, Retórica, 1, 1354a).

Em outras palavras, como a vitória da mentira e da injustiça é algo errado e mau, Aristóteles se propôs escrever um tratado que abordasse todas as questóes desse tema, para assim contribuir para a vitória da verdade e da justiça - desde o que chama de "corpo das provas" ('̇v $\theta \dot{u} \mu \eta \mu \alpha$, entimema = forma dedutiva de argumentação) até o estilo, mas também a clareza, o ritmo, a elegância retórica e os assuntos mais externos ao tema (como, por exemplo, os sentimentos das pessoas - a compaixão, a ira, o temor, a indignação, a inveja, a amizade, a inimizade, etc.). Para Aristóteles, a retórica abrangia, como podemos observar, o que hoje chamamos de psicologia. Claro: sem conhecer os sentimentos das pessoas, o retórico nunca conseguiria instigá-las, conquistá-las!

Aristóteles apresenta três tipos possíveis de discursos: 1) os judiciais (a respeito de fatos já ocorridos), 2) os deliberativos (decisóes possíveis de serem tomadas no futuro) e 3) os demonstrativos (nos quais náo era necessário decidir nada, apenas concordar [ou não], na qualidade de ouvinte, com as afirmações e os juízos de valor do orador). Pretendia assim abranger todos os âmbitos possíveis dos discursos (e argumentos), e preparar o estudante de retórica a ser capaz de argumentar racionalmente em prol da verdade.

Esses dois últimos pontos merecem destaque. Repitamos: para Aristóteles, a retórica deveria estar a serviço da verdade. Ademais, segundo ele, a verdade embasa a persuasáo do orador: 
As provas de persuasão fornecidas pelo discurso são de três espécies: umas residem no carácter moral do orador (ethos); outras, no modo com que se dispóe o ouvinte (pathos); e outras, no próprio discurso (logos), pelo que este demonstra ou parece demonstrar.

Além disso, é preciso ser capaz de argumentar persuasivamente sobre coisas contrárias, como acontece com os silogismos; não para fazer uma e outra coisa - pois náo se deve persuadir o que é imoral - mas para que não nos escape o real estado da questáo e para que sempre que alguém argumentar contra a justiça, nós estejamos habilitados a refutar os seus argumentos. (ARISTÓTELES, Retórica, 1354a-1355a, grifo nosso) ${ }^{2}$.

Detenhamo-nos um pouco nessa passagem. Em sua ordem. Quando os ouvintes sabem que o orador é íntegro, probo (ou seja, que não é corrupto!), o ouvem mais atentamente, pois ele merece crédito. Aristóteles chama isso de ethos ("̌́os). Nós, de ética. É o primeiro fundamento que convence o auditório. Em segundo lugar, o que proporciona veracidade ao discurso é a capacidade que o orador tem de conduzir emocionalmente a plateia conforme a intensidade de suas palavras. O filósofo chama isso de pathos ( $\pi \dot{\alpha} \theta 0 \varsigma$, isto é, tudo o que diz respeito à convulsão das emoçóes). São os sentimentos postos nas palavras

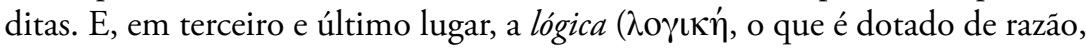
capacidade argumentativa, intelectual) do que é dito.

Portanto, das três provas de convencimento de um discurso, Aristóteles reconhece que a terceira, o raciocínio, é o elemento mais frágil na persuasão da audiência. As massas inicialmente não se convencem com argumentos, mas com a boa fama do orador e com sua emoção. Isso é verdade até hoje! Por isso, ele coloca a moral do orador (ethos) como a convicção mais forte, mais incisiva, pois quando uma pessoa correta discursa, todos ouvem com mais atenção, pois ela é moralmente íntegra! Não podemos deixar de lamentar: como essa percepção está distante de nós, acostumados que estamos com tanta corrupção na política!

Um último aspecto merece ser destacado nessa notável obra que é a Retórica de Aristóteles. É a clareza, para ele, suprema expressão enunciativa em um discurso. Falar com naturalidade, de modo direto e claro, para que todos entendam, não de modo vulgar, mas com belas metáforas e analogias

2 Por sua vez, o silogismo era o "tipo perfeito de raciocínio dedutivo" (PLATÃO, Teeteto, 186d), "discurso em que, postas algumas coisas, outras se seguem necessariamente" (ARISTÓTELES, Analíticos posteriores, I, 1, 24b). O exemplo mais comum é: "Todos os animais são mortais; todos os homens são animais. Logo, todos os homens são mortais.” 
(Retórica, 1405a), para que o discurso nunca seja estéril (ou frívolo), nem dito incorretamente (do ponto de vista gramatical). Falar de modo claro, com ritmo (1408b), elegância (1412a) e expressóes adequadas a cada gênero discursivo, são aspectos formais essenciais ao retórico. Tudo isso enaltece a verdade das palavras do orador.

Esses são, basicamente, os componentes aristotélicos que, séculos mais tarde (na Idade Média), deram origem ao núcleo da doutrina do ornato - o estudo das figuras de linguagem, das cores e dos tropos, mudanças de significados das palavras; por exemplo, em metáforas, alegorias, metonimias, hipérboles, eufemismos, etc.) - bela particularidade do estudo da retórica medieval que, com essa ênfase na valorização e na descrição das expressóes cotidianas, ordenadas e listadas, fazia com que os retóricos medievais considerassem como os aspectos mais previsíveis da fala, da oralidade.

\section{A retórica no MUNDo Romano}

\section{1. Cícero}

A difusão da doutrina retórica acompanhou pari passu a expansão romana pelo Mediterrâneo. Fixou-se na educação. Desde o séc. II a.C. até o final da Antiguidade, a retórica foi transmitida e retransmitida por toda a cultura ocidental, até chegar à Idade Média, especialmente através dos escritos de Cícero (106-43 a.C.) e dos pseudo-cíceros (textos que se pensavam terem sido escritos por Cícero, mas que a historiografia posteriormente definiu como apócrifos).

Cícero. Deste famoso advogado romano (mas também político, escritor, orador e filósofo), seus tratados de retórica mais importantes foram escritos no mesmo ano de 46 a.C.: Do orador e Brutus. O primeiro está dividido em três livros, e sua forma é a de um diálogo filosófico imaginário entre seis cidadãos (Marco Licínio Crasso, Marco Antônio, Públio Sulpício Rufo, Quinto Mucio Cévola, Quinto Lutácio Cátulo e Júlio César Estrabão), conversação imaginariamente ocorrida em 91 a.C.

O primeiro livro Do orador se ocupa: 1. dos três elementos da arte (dons naturais, técnica e prática), e 2. das partes do discurso-2.1. inventio (os argumentos), dispositivo (a ordem dos argumentos), elocutio (a ornamentaçáo com recursos estilísticos), memória (a memorização do discurso) e actio (a gesticulação e a dicção), e 2.2. dos sentimentos que devem ser incentivados na 
audiência - conciliare (como atrair o público), probare (como persuadir com argumentos) e movere (como emocionar os ouvintes).

No segundo livro, (o personagem) Marco Antônio ordena a oratória. Reveste-a com aquelas partes acima citadas e organizadoras do discurso (inventio, dispositio e memoria), enquanto outro dialogante, Crasso, discorre sobre as outras partes (elocutio e actio). A eloquência é explicada com os três tipos aristotélicos de discurso (judicial, deliberativo e demonstrativo). Marco Antônio nomeia as regras (conciliare, probare e movere) e compara as conciliare e movere com o ethos e o pathos grego. O ridiculum - a ironia - é uma parte importante da retórica, pois é um meio muito eficaz de persuasão.

No livro terceiro, Crasso expóe as duas qualidades da linguagem que todo bom orador deve cultivar: 1. a latinitas (tudo o que se refere ao latim como língua nobre e civilizada) e $\mathbf{2}$. a perspicuitas (a clareza, melhor forma de compreender um discurso). Explica ainda os três tipos de conhecimento necessários ao orador (a conjectura, a definição e a consequência), e enfatiza que o verdadeiro patrimônio oratório do falante deve ser a ornamentação (ornatos, a decoração do discurso com figuras estilísticas e literárias). Este último se divide em arcaísmos, neologismos e metáforas, reunidas com ordem e ritmo. Repitamos: a ornamentação deve ser ordenada e ritmada! Por fim, trata da actio, parte da ação oratória propriamente dita, com a voz e os gestos corporais.

Até quando, Catilina, abusarás de nossa paciência? Por quanto tempo tua loucura zombará de nós? Até onde chegará tua desenfreada audácia? Nem a guarda do Palatino, nem a ronda noturna da cidade, nem o temor do povo, nem a afluência dos bons, nem este local tâo bem protegido para a reunião do Senado, nem a expressão dos senadores, nada conseguiu te perturbar? Não te dás conta que teus planos foram descobertos? Não vês que tua conspiração já foi dominada pela prudência de todos? Quem, dentre nós, pensas tu que ignora o que fizeste na noite passada e na precedente, onde estiveste, com quem te encontraste, que decisão tomaste? Oh, tempos, oh, costumes! O Senado o conhece; o cônsul o sabe. (CÍCERO, Do orador, 1-2).

A sequência de perguntas, o tom exclamatório e incisivo, a força exposta na ordem do discurso (e, é claro, a tumultuada circunstância política do momento - Catilina estava presente!), tudo isso fez com que esse discurso ganhasse uma fama quase que imediata (a ele se seguiriam mais três catilinárias, todas proferidas naquele fatídico ano de 63 a.C.). Catilina se suicidaria naquele mesmo ano. 
Os historiadores reconhecem que os discursos de Cícero salvaram a República. Pelo menos momentaneamente, pois, logo a seguir, surgiria um furacão chamado Júlio César (100-44 a.C.).

\section{2. SÊNECA}

Devido à sua utilidade prática - jurídica, sobretudo, graças aos discursos advocatícios - a retórica foi, gradativamente, desconsiderada em Roma (apesar do prestígio que lhe atribuiu Cícero) ${ }^{3}$. No entanto, mesmo seus detratores, ainda que náo o soubessem, dela se valiam para seus pensamentos, para seus textos (tratados, cartas, etc.). Ela estava entranhada no pensamento romano. Vamos dar um belíssimo exemplo de sua utilização: Sêneca (4 a.C. - 65 d.C.), político, escritor e um dos maiores filósofos do estoicismo (filosofia que pregava uma sábia resignação diante das agruras da vida). Ao receber uma carta de seu discípulo Lucílio em que este se queixa da "falta de estilo" das cartas de seu mestre, Sêneca responde com uma "acusação" contra o que afirma ser uma "eloquência empolada", e incita seu aluno a ser honesto para consigo, a sentir as coisas com amor e não incorrer no erro da separação entre teoria e prática, isto é, na dissociação entre o que pensa, o que acredita, e sua vida real, seus atos no mundo.

Trata-se de um maravilhoso exemplo de utilização da retórica, mesmo para acusá-la de uma "eloquência empolada". Por isso, citarei sua primeira parte na íntegra. Devemos dar voz aos antigos, pois os grandes mestres do passado são belíssimos:

Tens-te queixado de receberes cartas minhas escritas sem grandes pruridos de estilo. Mas quem é que escreve com pruridos se não aqueles cuja pretensão se limita a uma eloquência empolada? Se nós nos sentássemos a conversar, se discutíssemos passeando de um lado para o outro, o meu estilo seria coloquial e pouco elaborado; pois é assim mesmo que eu pretendo sejam as minhas cartas, que nada tenham de artificial, de fingido! Se isso fosse possível, eu preferia mostrar-te o que sinto, em vez de o dizer. Mesmo que eu estivesse discutindo contigo náo me iria pôr na ponta dos pés,

\footnotetext{
3 "A instauração do regime imperial criava em Roma, no tocante à prática da eloquência, condiçôes análogas às que a monarquia lhe proporcionara havia vários séculos no Oriente mediterrâneo: estavam encerrados os grandes debates perante as assembleias, os processos em que se achavam implicados grandes interesses políticos; o orador só tinha a advogar, obscuramente, assuntos privados, ou então devia recorrer a discursos fictícios [...] Parece assim que, de maneira paradoxal, à semelhança do mundo grego, a retórica assumiu, definitivamente, posição dominante no ensino latino, no próprio momento em que perdia todo o interesse prático." (AYMARD; AUBOYER, 1958, p. 170).
} 
nem fazer grandes gestos, nem elevar a voz: tudo isto seriam artifícios de oradores, enquanto a mim me bastaria comunicar-te o meu pensamento, num estilo nem grandiloquente nem vulgar.

De uma coisa apenas eu te quereria convencer: de que sentia tudo quanto dissesse, e não apenas que o sentia, mas que o sentia com amor! Ninguém beija uma amante do mesmo modo que beija os filhos; e, no entanto, mesmo nas carícias puras e comedidas de pais para filhos está claramente visível a afetividade. Hércules me ajude! Eu não quero que as palavras inspiradas por um tâo magno assunto sejam excessivamente frias e secas pois a filosofia não deve renunciar por completo ao talento literário -, mas também não há que dar demasiada importância às palavras.

O nosso último objetivo deve ser este: dizer o que sentimos, sentir o que dizemos, isto é, pormos a nossa vida de acordo com as nossas palavras. Imagina um mestre qualquer: se a impressão que tu sentes contemplando as suas ações é idêntica à que tens ouvindo o seu discurso, esse mestre atingiu o seu propósito. Observemos a qualidade dos seus atos, a fluidez do seu discurso: entre ambos, a mais perfeita unidade! As nossas palavras não visam o prazer literário, mas sim a pertinência. Se a eloquência surge, por assim dizer, naturalmente, sem esforço, ou quase, deixemo-la acompanhar as mais nobres açóes e realçar, não a sua presença, mas a ação em si! As restantes artes se dirigem exclusivamente à inteligência, ao passo que a filosofia é a atividade por excelência da alma. Um enfermo não exige do médico o brilho do estilo; se, todavia, o mesmo homem sabe tratar da doença é também capaz de explicar num estilo agradável qual o tratamento a seguir, deverá fazê-lo.

Isso não significa que o doente se considere muito afortunado por ter encontrado um médico eloquente, tal como de nada adianta que um piloto experimentado seja simultaneamente um belo homem. Para quê acariciar-me os ouvidos, para quê deleitá-los? Apliquem-me um cautério, uma lanceta, uma dieta rigorosa. Esta é a tarefa real. A tua preocupaçáo deve ser a de sanar uma enfermidade enraizada, grave, generalizada; a tua tarefa é tăo ingente como a de um médico que trata uma epidemia. Para quê preocupar-te com as palavras? Dá-te por satisfeito se estiveres à altura dos teus deveres. Quando aprenderás as grandes liçóes da filosofia? Quando interiorizarás a lição aprendida de modo tal que nunca mais a esqueças? Quando porás à prova a teoria? $\mathrm{Na}$ filosofia não basta, como é o caso nas outras ciências, confiar na memória, devemos pô-la à prática através da ação. Para ser feliz não basta conhecer a teoria, há que a pôr em prática. (SÊNECA, Carta 75). 
Com uma retórica contra a retórica, Sêneca chama a atenção de seu aluno para o que realmente importa: a vida coerente, vida vivida sem contradiçóes, com uma conexáo profunda entre pensamento e ação, entre ideias e atos.

\section{3. Quintiliano}

Mas o ápice do pensamento a respeito da retórica - a sistematização do pensamento ciceroniano unida à tradição clássica grega - foi sintetizada na obra Instituição oratória (95 d.C.), texto enciclopédico, de Quintiliano (35-95) professor e advogado. Curiosamente, ela foi lançada justamente em um período em que a prática da retórica estava em franca decadência, pois não era mais praticada nem no Senado nem no Fórum, estava "limitada" às escolas e circunscrita à formação cultural do cidadão romano. A retórica havia se inserido na cultura, era $a$ cultura própria da civilidade, da romanidade!

Quintiliano define e insiste no caráter do orador, tema repetidamente tratado, como vimos, de Aristóteles a Cícero, e coloca a retórica como disciplina protagonista da educação. O principal objetivo da Instituição é colocar a retórica a serviço da formação integral dos jovens. Como nada é indiferente a ela e somente o homem bom pode ser um orador perfeito, o professor deve incutir nos alunos as virtudes do espirito - uma vida correta e honesta, com justiça, coragem, temperança e outras virtudes semelhantes a essas (uma das grandes heranças temáticas que a Antiguidade legará ao mundo medieval: o tema das virtudes e dos vícios).

O orador deve procurar a perfeição e chegar à sabedoria, nos costumes, no conhecimento e na habilidade de falar, mesmo que ninguém tenha conseguido isso. Caso pareça uma exigência muito elevada, não importa: sempre deve ser ensinado às crianças o que há de melhor - a educação deve ser exemplar. Por isso, o mestre deve investigar os espíritos dos alunos (pois alguns são preguiçosos, outros se enervam com as ordens, outros são medrosos, outros progridem com um trabalho contínuo: cada criança tem características específicas).

Quintiliano critica as surras na educação: é algo degradante, digno de escravos e injurioso. Ninguém aprende assim. Defende ele uma educação integral, isto é, com a retórica intimamente associada às outras disciplinas. Em primeiro lugar, a gramática, a música, a filosofia e a poesia. Aqui se percebe claramente o caráter totalizante da formação clássica: para estudar-se retórica, por exemplo, é imprescindível aprender música: 
4. Não é suficiente ter lido os poetas: é necessário estudar a fundo todas as espécies de escritores, não tendo em vista o conteúdo, mas as expressões que frequentemente adquirem legitimidade pelos autores. Tanto não pode a gramática ser perfeita sem a música que é preciso ensinar-lhes os metros e os ritmos; se desconhecer o movimento dos astros não entenderá os poetas que, para deixar de lado outros pontos, tantas vezes usam o nascer e o ocaso dos astros para a determinação dos tempos; também não se pode desconhecer a filosofia, tanto por causa de referências muito numerosas, em quase todos os poemas, tiradas das mais abstratas questóes naturais como os de Empédocles, entre os gregos, os de Varrão e de Lucrécio entre os latinos - que legaram em versos os preceitos da sabedoria.

6. Nessas circunstâncias, que ninguém desdenhe como secundários os elementos da gramática, não porque exija um grande esforço distinguir as consoantes das vogais e dividi-las em elenco de semivogais e mudas, mas porque, adentrando o interior desse mistério, surgirão muitas sutilezas das coisas que podem aguçar não apenas as inteligências juvenis, mas também manifestar até erudição e ciência altíssima. (QUINTILIANO. Instituição oratória, livro I, 4, 6).

Os especialistas dividiram a obra de Quintiliano em quatro partes: 1) a pedagogia: o exercício da oratória e as condiçóes que a tornam possível (livros I e II); 2) a funçâo da oratória (livro III); 3) seus preceitos (livros IV-XI); 4) exemplos comentados de poetas e prosistas e a imagem do orador perfeito (livros X-XII).

Apesar de fundamental na história da retórica, a obra de Quintiliano recebeu poucas cópias na Idade Média - duas no séc. IX e outras duas no séc. $\mathrm{X}$ (justamente no período chamado de Renascimento Carolíngio, o primeiro momento em que a sociedade medieval se voltou para o mundo antigo em busca de referenciais educacionais, literários e filosóficos). Mesmo assim, talvez também devido ao fato de a obra ser bastante volumosa, essas quatro cópias são incompletas e chegaram até nós um pouco mutiladas.

Em outras palavras: a influência de Quintiliano na educação da retórica foi bastante restrita durante toda a Idade Média. Seria necessário aguardar a Renascença (sécs. XIV-XVII) - o quarto renascimento europeu [o primeiro, no séc. IX (Renascimento Carolíngio), o segundo no X (Renascimento Otoniano), e o terceiro, o Renascimento do século XII] para que Quintiliano fosse definitivamente redescoberto, em especial após a edição corrigida de Rafael Régio (c. 1440-1520), humanista veneziano que, além de corrigir os erros das ediçôes medievais da Instituiçâo oratória com sua crítica textual, conseguiu, 
além disso, provar que a obra Retórica a Herênio (c. 86-82 a.C.) não havia sido escrita por Cícero.

\section{4. RETÓRICA A HERÊNIO}

Na verdade, mais do que a Instituição oratória, a Retórica a Herênio foi a obra que mais influenciou a tradição dos estudos retóricos medievais. Não conhecemos seu autor. É dividida em quatro livros: 1) o ofício do orador, as partes do discurso e os gêneros da narração; 2) os gêneros das causas que movem o orador, as constituiçôes legais, as partes do direito e da argumentação; 3) os gêneros, a disposição e a pronunciação, a configuração da voz e a memória, e 4) a elocução, suas figuras e comodidades.

Nessa estrutura, a Retórica a Herênio inova: acrescenta a memória às costumeiras fases de elaboração do discurso - se entenda memória como a capacidade do orador de recordar os temas e a ordem de seu discurso com determinadas técnicas aprendidas com a retórica. Esse será um aspecto dos estudos retóricos que terá grandes e importantes consequências para a consolidação e desenvolvimento da educação ocidental, como já estudamos noutra oportunidade! (COSTA, 2008).

A inventio é bastante analisada (livros I e II), a dispositivo é também tratada (livro III), mas é sobretudo o livro IV que oferece uma importante síntese dos conhecimentos até então acumulados sobre a elocutio (e que também exercerá uma profunda influência nos séculos posteriores): a doutrina dos três gêneros estilísticos (elevado, médio e simples) e seus vícios correspondentes, além da reflexão sobre as virtudes do estilo (elegância, composição e dignidade).

Em toda essa análise das virtudes necessárias ao orador, a Retórica a Herênio se preocupa com a correçáo e a claridade do discurso (ser claro sempre foi uma qualidade admirada pelos retóricos!), com a cuidadosa escolha das palavras (para evitar, por exemplo, as aliteraçōes e os hiatos) e com as figuras de linguagem com a devida ornamentação (na exortação aplicada ao pensamento e a correta dicção das palavras). Todas essas preocupaçóes com a qualidade formal do discurso deveriam estar assentadas, como estamos destacando a todo o momento e em todos os períodos históricos, com a ética e os valores morais:

No debate político, a utilidade se divide em duas partes: a segura e a honesta. $[\ldots]$

A matéria honesta se divide no reto e no louvável. Reto é o que se faz com virtude e dever. Subdivide-se em prudência, justiça, coragem e modéstia. 
Prudência é a destreza que pode, com certo método, discernir o bem e o mal. Também se denomina prudência o conhecimento de alguma arte, e ainda a memória de muitas coisas e o trato de um grande número de negócios. Justiça é a equidade que confere o direito de algo a alguém conforme sua dignidade. Coragem é o apetite das coisas maiores e o desprezo das menores; é também a perseverança frente às dificuldades em razão da utilidade. Modéstia é a moderação que limita, no ânimo, nossos desejos. [...]

Usaremos as partes da justiça se dissermos que é preciso apiedar-se dos inocentes e dos suplicantes; se evidenciarmos que convém gratificar os que merecem o bem; se demonstrarmos que é preciso punir os que merecem o mal; se declaramos que a fé deve ser guardada a todo o custo; se dissermos que é preciso preservar principalmente as leis e os costumes da cidade, que convém cultivar com zelo as alianças e amizades; se mostrarmos que deve ser religiosamente cultuado o que a natureza estabelece como justo quanto aos pais, os deuses e a pátria; se dissermos que a hospitalidade, a clientela, a consanguinidade e a afinidade devem ser escrupulosamente cultivadas; se demonstrarmos que nem o dinheiro, nem os favores, nem os riscos, nem a rivalidade nos podem desviar do caminho reto; se dissermos que em tudo convém que o direito seja estabelecido equitativamente. Se ponderarmos sobre uma açáo na assembleia ou no conselho, com essas e outras partes da justiça mostraremos que é justa, com o que for contrário a essas partes, injusta. Assim, com os mesmos tópicos, estaremos preparados para aconselhar e desaconselhar. (Retórica a Herênio, livro III, 3-4).

Nessa belíssima passagem, salta aos olhos o estilo: as repetiçóes retóricas, as ênfases, a colocação dos verbos e dos adjetivos. Como os antigos adjetivavam! E como enfatizavam a necessidade do ensino com ética - ainda que, na prática, tanta antiética fosse praticada! A seguir, nessa mesma passagem, o enaltecimento da coragem e da modéstia toca tão fundo na arrogância e na covardia de nosso tempo que merece que nos despeçamos da Retórica a Herênio com ela:

$\mathrm{Se}$, por outro lado, dissermos que se deve agir em nome da coragem, mostraremos que é preciso perseguir e desejar coisas grandiosas e elevadas. Por isso, os corajosos devem desprezar as coisas baixas e indignas de homens corajosos, julgando-as não idôneas à sua dignidade. Mais: é necessário não se desviar do que é honesto, não importando o tamanho do risco ou do sofrimento. Antes a morte que a torpeza. Nenhuma dor deve afastar do dever; que não se tema a inimizade de ninguém quando se defende a verdade; pela pátria, pelos pais, pelos hóspedes, pelos amigos e pelas coisas que a justiça nos impele a cultivar, se enfrenta qualquer perigo e se suporta qualquer fardo. 
Usaremos as partes da modéstia se vituperarmos o desejo excessivo de honrarias, de dinheiro e de similares; se mantivermos cada coisa no seu limite definido pela natureza; se mostrarmos o quanto é suficiente em cada caso; se dissuadirmos a busca do que é excessivo e estabelecermos a medida de cada coisa. Partes da virtude como essas devem ser amplificadas se as aconselharmos, atenuadas se delas dissuadirmos, de modo que o que mostrei seja enfraquecido. Com efeito, não haverá quem prescreva o abandono da virtude. (Retórica a Herênio, livro III, 5-6).

Com o enaltecimento da justiça e da coragem, da virtude e da modéstia, nos despedimos da retórica clássica. A medieval herdou esses temas, e a virtus romana foi metamorfoseada e enriquecida com as virtudes cristâs - às cardeais (prudência, justiça, fortaleza e temperança), platônicas, o cristianismo acrescentou as teologais ( $f e ́$, esperança e caridade). Assim nascia a Idade Média. Assim a retórica foi cultivada.

\section{A RETÓRICA MEDIEVAL E A BOA-NOVA DO EVANGELHO}

Os primeiros séculos cristãos presenciaram a permanência da retórica, mas aplicada a declamaçôes cerimoniais e a treinos escolares, especialmente com a recuperação de uma série de exercícios retóricos provenientes da Grécia antiga chamados de progymnasmata ("exercícios preliminares"), com ênfase nos motivos laudatórios (ou de censura) - isto é, com destaque para a moral. $\mathrm{Na}$ história do tema, esse período é conhecido como segunda sofistica, pois foram os professores das escolas sofistas que se destacaram, já que seus discursos e ensinamentos se aplicavam bem às circunstâncias históricas do momento, pois ajudavam a confirmar os valores religiosos e morais da sociedade romana ocidental. Continuavam a ser criticados por sua "retórica oca", isto é, vazia de significado existencial, mas influenciaram aqueles mesmos pregadores cristáos que os criticavam.

\section{1. Os PANEGÍRICOS}

O cristianismo passou a ser a religião oficial do Império no séc. IV. O historiador Paul Veyne (1930- ) dedicou uma de suas pesquisas a esse decisivo período da história ocidental (VEYNE, 2010). Nesse século crucial, tanto imperadores quanto oradores que celebravam as virtudes com a retórica já eram cristãos, e a educação sofística também é claramente perceptível nos 
sermóes panegíricos (elogios públicos a pessoas ilustres) e nas oraçóes funerárias dessa época. Com a progressiva orientalização da corte imperial-especialmente a partir de Diocleciano (244-311) - passou a ser um costume celebrar as virtudes do imperador com panegíricos em um evento literário encenado. Já em 336, o bispo e historiador da Igreja Eusébio de Cesaréia (c. 2263-339) ofereceu um panegírico ao imperador Constantino I, o Grande (c. 272-337), no trigésimo ano do seu reinado, e celebrou sua piedade (pietas), ao invés de suas conquistas militares, o que, por si só, foi uma novidade típica das transformaçóes culturais realizadas pelo cristianismo.

Assim, redigir um panegírico elegante e gracioso - especialmente se fosse na forma de um poema em versos hexâmetros (como na Ilíada) - passou a ser uma condiçáo necessária para qualquer pessoa bem-educada atrair a atenção de algum patrocinador. Por exemplo, o poeta Claudiano (c. 370-404) conseguiu sua reputaçáo com um panegírico em louvor ao imperador Honório (384-423); o político Cassiodoro (490-581) deixou um livro de panegíricos.

Não deixa de ser curioso que a retórica, nesses primeiros séculos cristãos, tenha passado a ser usada em um tipo de escrito no qual se esperava que fosse excessivo, um elogio desmedido, não exatamente verdadeiro, ainda que nos limites do decoro e do constrangimento! Cada tempo tem sua particularidade cultural. Seja como for, os primeiros Padres da Igreja escreveram sermóes panegíricos dedicados às festas do ano cristão e a cerimônias funerárias. Em relação a esse último ponto, é importante recordar que, com o cristianismo, houve uma notável mudança de atitude da sociedade em relação com a morte e os mortos. De uma parte, pela incorporação do mundo interior pela arte romana (com a consequente ampliação da gama de sentimentos representados); por outro, com a aproximaçáo dos vivos e dos mortos por meio da penetraçáo dos cemitérios nas cidades e vilas, entre as habitaçóes dos homens (os romanos pagãos, pelo contrário, fugiam da morte com os mitos, estetizavam a morte: seus cemitérios eram localizados fora das cidades). O historiador Peter Brown (1935- ) foi taxativo: com sua propagação da boa-nova a todos, o cristianismo se apresentou como uma moral realmente universalista, arraigada num sentimento novo e na igualdade de todos diante de sua lei. Foi a mais profunda revolução do período clássico tardio. Cresceu com a pregação e formou uma profunda base de noçóes morais difundidas entre milhares de pessoas humildes (BROWN, 1990). 


\section{2. Agostinho e Marciano Capela}

A transformação do mundo antigo no medieval merece, sempre, uma explicação, mesmo que sucinta, como a nossa. E de todos os autores cristãos desse período de transição que já foi chamado de Antiguidade tardia, aquele que estabeleceu os fundamentos da retórica cristã (aproveitando-se de seus conhecimentos clássicos, especialmente de Cícero) foi Santo Agostinho (354-430). Ele se valeu da retórica em várias passagens de sua monumental obra $A$ cidade de Deus (c. 412-426), quando explicou e interpretou textos (especialmente a Bíblia). Por exemplo, quando discorreu sobre o sentido do descanso de Deus no sétimo dia da criação [que deve ser compreendido como uma figura de linguagem - "o repouso de Deus significa o repouso dos que n'Ele descansam, assim como a alegria de uma casa significa a alegria dos que nela se alegram" (XI, 8)]; quando abordou a essência de Deus e a ordenação das naturezas segundo os graus de Sua essência e o sopro divino na alma (XIII, 11 e 24); quando analisou o sentido de amor e de afeição e as perturbaçôes na alma do sábio estoico (XIV, 7 e 8); quando discorreu sobre o amor da cidade de Deus e o amor da cidade dos homens (que nada mais é, para ele, do que o amor pelos corpos das mulheres) (XV, 22).

Há muitas outras passagens em que o bispo africano trata da retórica, especialmente para explicar a gramática - recordem que essas eram duas das três disciplinas ensinadas nas escolas antigas: na ordem, 1) gramática, 2) dialética e 3) retórica (1. aprender a ler e a escrever corretamente; 2 . a raciocinar e apresentar assuntos ordenadamente, e 3. a fazer essas duas coisas belamente). Mas Agostinho utiliza a retórica (e de um modo sumamente belo) somente no fim de sua obra. No cap. V do livro XXII da Cidade de Deus, há um jogo de palavras - crivellincrivel - a respeito do mundo acreditar em duas coisas incriveis: que o corpo de Cristo ascendeu aos céus e que os corpos serão ressuscitados. É inacreditável que o mundo creia no que é incrível! Mais: é também incrível que os apóstolos - homens incultos, da mais baixa condiçáo, poucos, desconhecedores da gramática, das armas da dialética e sem a intumescência da retórica - tenham, com seus testemunhos, não com a eloquência de suas palavras, mas com testemunhos tão desprezíveis, feito o mundo acreditar neles! Se isto não é crível, como toda a Terra nisso acredita? Se pelo menos fossem muitos, doutos e ilustres por seus altos postos os que tivessem afirmado, náo seria de admirar que o mundo neles acreditasse. Mas é incrível que aqueles homens simples tenham convencido o mundo! Para Agostinho, só isso já é um milagre, grande e único: o de toda a Terra ter acreditado nisso sem milagres! 
No livro IV (“Sobre a maneira de ensinar a doutrina”) de outra obra, a Doutrina cristã (c. 397), Agostinho faz uma reflexão retórica e utiliza o ideal (e binômio) ciceroniano da sabedoria associada à eloquência para tratar de todos os gêneros possíveis de eloquência sagrada. Por isso, defende que é inútil apenas ser eloquente, pois à autêntica sabedoria nunca falta a eloquência: mais vale falar com sabedoria do que com eloquência (IV, 5, 7), já que os autores e profetas das Sagradas Escrituras e os hagiógrafos associam as duas, e de modo encantador (IV, 6, 10)! Analisa várias passagens bíblicas, defende a clareza (IV, 10, 24) e a elegância (IV, 11, 26); afirma que se deve instruir, que não é errado agradar, desde que não se fuja da verdade, e que a missão do orador cristão é converter. A esses três objetivos (instruir, agradar e converter) correspondem três tipos de estilo (e cita Cícero): simples, médio e sublime. Dá exemplos de pregadores cristãos que se valeram desses estilos, e aconselha mesclá-los, a depender da ocasião. Como os antigos, Agostinho também defende a coerência entre discurso e prática (IV, 28, 59), para assim o orador ser um modelo para os fiéis. E que o cristão sempre deve se apegar mais à verdade do que à forma (IV, 29, 61)!

A retórica cristã defendida por Santo Agostinho era instrutiva, popular e religiosa. Instrutiva porque ensinava os apologéticos a descobrir e difundir a verdade; popular porque era dirigida a todos, não a um povo ou cultura particular, e religiosa porque encontrava toda a sabedoria necessária para sua missão na Bíblia, não na filosofia (ainda que esta estivesse a serviço da fé). Por fim, é bom explicitar que o pensador cristão colocou sua ênfase na expressão retórica baseada na verdade, mas não na verdade filosófica socráticoplatônica-aristotélica, mas na verdade da fé. Todo o desenvolvimento posterior da retórica (pelo menos até o séc. XI) teve no santo africano uma de suas bases mais sólidas.

Devido ao intrínseco caráter apologético da religião cristã - "ide por todo o mundo e pregai o evangelho a toda criatura" (Mc 16, 15) - praticamente todos os escritores cristãos se dedicaram, em maior ou menor grau, a especulaçóes teológicas, filosóficas ou literárias de natureza retórica. Cassiodoro (c. 485580) dedicou um espaço à retórica nos estudos monásticos [em sua obra Instituiçôes (livro II, cap. 2)] e também uma das obras mais influentes de todo o período medieval (até a Renascença!), Sobre as bodas da filologia com Mercúrio, do escritor neoplatônico Marciano Capela (séc. V), um dos últimos suspiros da tradição literária pagá, tratou dela (pois comentou todas as artes liberais). Nela, a retórica é alegoricamente apresentada como uma belíssima dama, 
com um cinto ornado de joias (que representa seus ornamentos retóricos), um vestido ornado com suas figuras de linguagem e armada de modo a causar dano a seus adversários - a linguagem pode ferir! Ela irrompe ao som de trombetas no livro $\mathrm{V}$ das Bodas, elegantemente acompanhada pelos famosos oradores Demóstenes (grego) e Cícero (romano).

Em sua exposição nas Bodas, a retórica apresenta a estrutura e o conteúdo de sua arte: a investigação e organização dos argumentos, a melhor locução das palavras, a necessária memorizaçáo e o modo preciso de falar com a devida voz e os gestos corporais. Explica seus tropos (figuras de linguagem que alteram o significado - perífrases, metáforas, etc.) e suas figuras literárias.

\section{3. De Isidoro de Sevilha ao Renascimento do século XII}

Mas um dos que mais contribuíram para assentar a retórica na educação cristã foi o bispo Isidoro de Sevilha (c. 560-636). Em suas Etimologias há uma bela definição dessa arte:

A retórica é a ciência de falar bem nas questôes cívicas e com os adequados recursos da eloquência para persuadir o que é justo e o que é o bem. $\mathrm{O}$ nome retórica deriva do grego rhetorídsen, que quer dizer "recurso da palavra", já que entre os gregos "palavra" se chama rhésis e, orador, rhétor. A retórica está inseparavelmente ligada à arte da gramática. Com a gramática aprendemos a falar corretamente e, com a retórica, a expor os conhecimentos adquiridos. [...]

O orador é um homem bom, perito na arte de falar. A retidáo do homem se baseia em sua natureza, em seus costumes e em suas qualidades. Sua experiência se baseia em uma eloquência regulada por normas e que tem cinco partes: invenção, disposição, elocução, memória e pronunciação. $[\ldots]$

Fala com pureza latina aquele que utiliza palavras apropriadas e verdadeiras sem distanciar-se da maneira de falar e da elegância próprias da época em que vive. Quem se expressa dessa maneira não considera suficiente meditar o que diz, mas dizê-lo com clareza e de modo suave. Mais: deve praticar o que diz! (SANTO ISIDORO DE SEVILHA, Etimologias, II, 1, 1-2; 3 , 1 , e 16, 2).

Todos esses foram autores de transição, isto é, escritores que transmitiram à Idade Média Central (sécs. XI-XIII) a herança clássica, não só a respeito da retórica, mas de todo o conhecimento da Antiguidade. Ainda que parcial, 
ainda que incompleto. Quando Carlos Magno (748-814) incentiva as Letras e impulsiona o Renascimento Carolíngio (com a fundação de escolas, a contratação de professores e a reforma de mosteiros), a gramática é a primeira arte a ser valorizada. Cícero é copiado, comentado, e novos tratados de eloquência são escritos - Alcuíno (735-804) e Rábano Mauro (c. 780-856), além de cartas, homilias e tratados, redigem obras de gramática, de dialética e de retórica; no Renascimento do século XII, a retórica é examinada à luz de Boécio (c. 480-524), outro escritor de transição muito influente.

Os mais importantes tratados do Renascimento do século XII que tratam ou aludem ao tema - de Thierry de Chartres (†1150), de Guilherme de Conches (c. 1090-1154), de Hugo de São Vítor (c. 1096-1141) e de João de Salisbury (c. 1120-1180) - abordam a retórica centrados na inventio ciceroniana (os argumentos retóricos, também analisados na Retórica a Herênio, como vimos) ou a subordinam à dialética. Assim, de um modo ou de outro, a retórica foi transmitida e retransmitida pelos medievais, especialmente sob a influência dos escritos de Cícero, autor muito apreciado na Idade Média, pelo menos desde Pedro Abelardo (1079-1142), até Ramon Llull (1232-1316), Petrarca (13041374) e o humanismo (sécs. XIV-XVI). Todos os autores cristáos educados a partir do séc. IX se valeram dela para redigir seus textos. Um dos mais belos exemplos dessa associação da tradição clássica com a sabedoria cristã são os escritos do abade cisterciense São Bernardo de Claraval (1090-1153).

\section{4. Bernardo de Claraval}

Personagem catalizador de seu tempo, Bernardo também é uma maravilhosa síntese da fusão clássica, da literatura dos antigos, com sua tradiçẫo, a cristã. O monge é tão solicitado que dita seus textos, suas cartas, a vários secretários: de modo impressionante, cita a Bíblia de cor (e mostra assim a força da memória medieval, aspecto da pedagogia da época táo sublinhado, inclusive pelos tratados retóricos, como vimos), e aplica as passagens sagradas recordadas com situaçóes reais, vividas. Por ele e por aqueles que solicitam seus conselhos. A forma de sua redação é a clássica, mas adocicada, adornada com o amor de Cristo - do mesmo modo, suas reprimendas, suas críticas e acusaçôes, sempre dirigidas em defesa de sua fé, são aguçadas com a espada de sua retórica. Por isso o abade ficou conhecido como melifluo (que escorre mel), mas também, segundo seus detratores, amargo como o fel. Ambas as faces são pródigas filhas de sua impressionante retórica. 
Assim como fiz acima com o primeiro discurso de Cícero (sua primeira Catilinária), selecionei o início da primeira carta do Epistolário de Bernardo, texto dirigido a um sobrinho que fugira de seu mosteiro e passara a detratá-lo publicamente por impor sua rigidez de vida a seus monges. Trata-se de uma obra-prima retórica: Bernardo, com a consciência pesada por ter sido muito duro com o parente ainda adolescente, toma a iniciativa. Escreve a ele. Não é possível citar o texto inteiro, que inicia em tom de um pedido de perdão, mas termina como se exigisse que ele voltasse, para que náo incorresse em pecado. A fluência retórica que vai de um extremo ao outro só pode ser percebida (e apreciada) com a leitura integral da carta. Mas seu início já pode nos oferecer a notável qualidade retórica de seu texto (e nos fazer entender porque o abade foi tâo influente em sua época). Além disso, há ali o que considero a melhor definição do que é o amor, o verdadeiro amor - a caritas cristã, desinteressada, que deseja "apenas" o bem do próximo [amor que já foi definido pela filósofa Hannah Arendt (1906-1975) como amor perfeito, porque puro, sem interesse].

O amor desinteressado é outro belo fruto da tradição medieval cristã. Vejamos como a retórica ornamenta o pensamento do religioso:

Diletíssimo filho Roberto, esperei até o limite do possível, confiando que talvez a piedade de Deus se dignasse a visitar tua alma por si e a minha por ti, isto é, que Ele infundisse em ti a saudável compunção e em mim a grande alegria de tua salvação. Mas já que até agora me senti frustrado em minha expectativa (Sl 119,116), não posso encobrir mais a minha dor, nem reprimir a minha ansiedade, nem dissimular a minha tristeza. Por isso, mesmo contra toda a ordenação jurídica, minha ferida me induz a chamar àquele que me feriu e a desprezadamente requerer àquele que me desprezou, humilhando-me para satisfazer a injúria de meu injuriante, e rogando a quem devia me rogar.

Claro que a dor excessiva não delibera nem se ruboriza, não consulta a razão, não teme o dano da própria dignidade, não se atém à lei, não aquiesce com o juízo; ignora o modo e a ordem, pois, antes de tudo, busca uma soluçáo para o sofrimento ou o gozo do que falta. Tu poderás replicarme: "Eu não feri ninguém, e a ninguém desprezei. Pelo contrário: eu fui o ferido e desprezado de mil maneiras; limitei-me a fugir de meu malfeitor. A quem eu injuriei fugindo das injúrias? Não é melhor distanciar-se do perseguidor que viver aguentando-o? Não é preferível fugir daquele que te fere que feri-lo?"

Estou de acordo. Não pretendo discutir, mas dirimir a discussão. Fugir da perseguição não é culpa do fugitivo, mas do perseguidor. Não o contradigo. Omito os fatos, não discuto as culpas, não retrato as causas, não recordo as injúrias. Isso só serve para instigar as discórdias, não para mitigá-las. 
Somente quero falar o que mais me afeta. Sofro muito porque não te tenho ao meu lado, náo te vejo, pois vivo sem ti e, para mim, morrer por ti é viver, e viver sem ti é morrer. Não me pergunto por que fostes; o que me dói é que não voltes. Não denuncio as causas de tua partida, mas a dilação de teu regresso. Vem e façamos as pazes; volta e satisfaça meus desejos. Vem, insisto, volta que eu cantarei com gozo: "Fora morto e reviveu; fora perdido e encontrado". (BERNARDO DE CLARAVAL, Carta 1).

Reparemos como o pensamento bíblico adornou a forma retórica: para alicerçar o início de sua carta, Bernardo citou indiretamente duas passagens, Salmos e Lucas (de acordo com a Vulgata, tradução utilizada na época). Em Sl 119,116, o trecho é: "Sustenta-me, Senhor, conforme Tua palavra, e eu viverei e não me confundirei em minhas expectativas." Ao aplicarmos esse trecho à passagem da carta, interpreto que sua intençăo literária e teológica foi que nem seu rogo a Deus o impediu de confundir-se com suas esperanças em relação ao seu sobrinho. Por sua vez, em Lc 15,24: "Meu filho estava morto e está novamente vivo; estava perdido e foi encontrado. E todos começaram a regozijar-se." A aplicação da passagem na carta parece clara: caso seu sobrinho volte à abadia, Bernardo se alegrará do mesmo modo que o pai da parábola de Cristo, que comemorou efusivamente o retorno do filho errante.

Ademais, toda a construção do argumento inicial da carta tem a retórica como princípio: as repetiçôes, as exclamaçóes, a imaginação de como o receptor responderá à súplica ao lê-la e, principalmente, a ênfase no amor, em sua pungente e emotiva definição.

Com seus escritos, Bernardo de Claraval fundiu a herança clássica com o manancial cristáo que alimentou e preservou a cultura da Europa por séculos. É um dos representantes do Renascimento do século XII, do ponto de vista literário. Seus textos abundam dos recursos retóricos ensinados nas escolas monásticas e lidos nos tratados copiados nos scriptoria medievais (normalmente salas adjuntas às bibliotecas em que monges faziam cópias de textos antigos e religiosos). A retórica prosseguia em sua trajetória educacional. 


\section{5. Ramon Llull e a Retórica nOVA (1301): o CONCEITO DE ORDEM}

Imagem 2

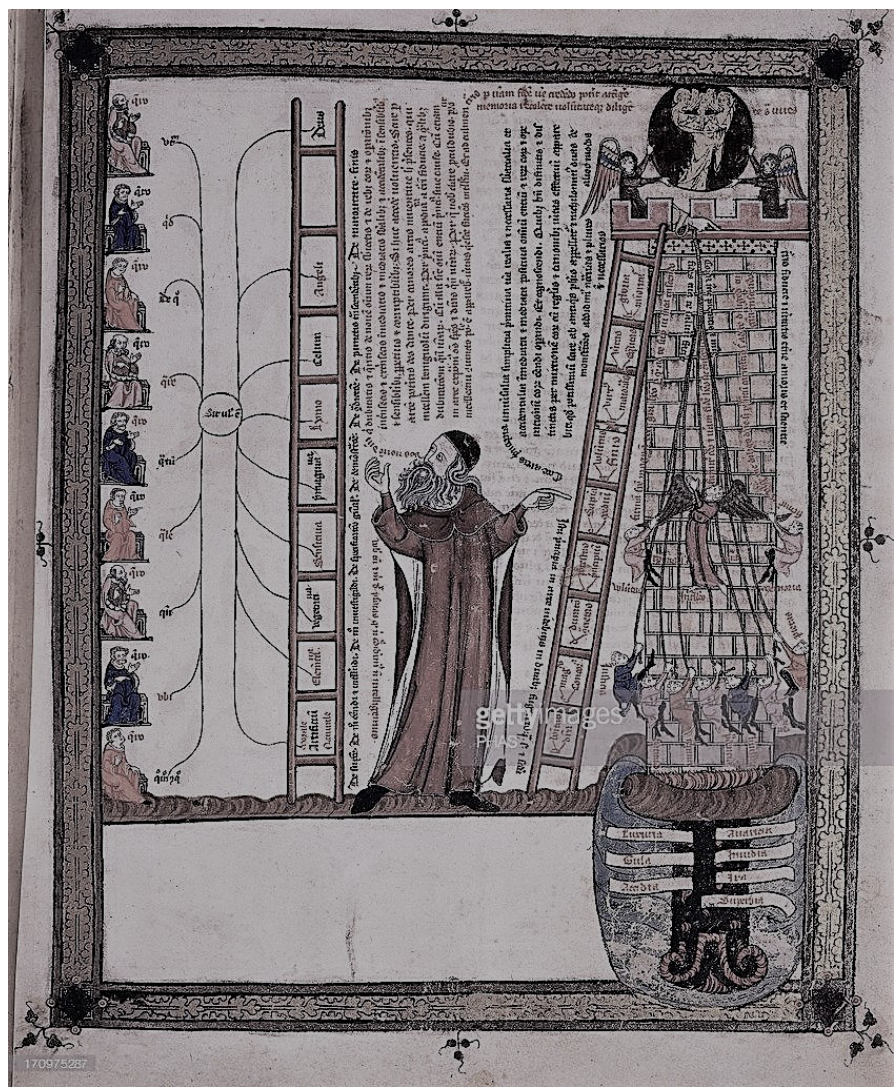

Iluminura V do Breniculum (c. 1325, St. Peter perg. 92, folio 5r). Baden Memorial Library. Karlsruhe, Alemanha. Foto: Prisma/UIG via Getty Images (public domain).

$\mathrm{Na}$ imagem 2, iluminura $\mathrm{V}$ do Breniculum - manuscrito com recopilações de obras do filósofo Ramon Llull (1232-1316) feito às expensas de seu discípulo, o médico parisiense (e cônego de Arras) Thomas Le Myésier $(\dagger 1336)$, o filósofo catalão está no centro da cena. Ágil, com uma postura corporal inquieta - expressáo de sua filosofia e de seu temperamento - ele gesticula e olha para a esquerda, onde nove discretos personagens sentados, filósofos, representam as nove dúvidas possíveis sobre os nove sujeitos do universo: são as 
questôes aristotélicas (se?, o que?, de que?, por que?, quanto?, qual?, quando?, onde?, como? e com que?). Essas questóes estavam há muito relacionadas com as classes gramaticais (no grego são nove; no latim, oito; no português, dez: substantivo, artigo, adjetivo, numeral, pronome, verbo, advérbio, preposição, conjunção e interjeição) - recentemente, o gramático brasileiro Carlos Nougué (1952- ) relacionou filosoficamente as noves questóes aristotélicas com os nove acidentes da substância que definem, por fim, as classes gramaticais - abro esse pequeno parêntese para mostrar o quanto a gramática está associada à dialética (e a retórica nunca se furtou a esse diálogo fundante da capacidade de raciocínio e de abstração, base de toda a história do pensamento).

Bem, volto à iluminura do Breuiculum. Aqueles sujeitos sentados e verticalmente enfileirados à esquerda fazem, por sua vez, perguntas à escada da arte de Ramon Llull (à esquerda do filósofo). Ao centro, Llull explica seu método (por isso sua agitação). À direita, uma metáfora imagética: a Torre da confiança, da sabedoria e da verdade - de cima para baixo, a Trindade (no cume da Torre) e, pendurados em uma corda, três anjos (que representam a vontade, o intelecto e a memória, tríade agostiniana que se pensava como uma projeção da Trindade na alma) e sete personagens na parte mais baixa da corda que representam as sete virtudes necessárias para ascender-se intelectualmente (a justiça, a fortaleza, a temperança, a prudência, a humildade, a paciência e a piedade). Eles fogem dos vícios (no subsolo da Torre) - a luxúria, a gula, a acidia, a avareza, a inveja, a ira e a soberba (na filosofia de Ramon, as virtudes combatem os vícios).

Essa iluminura é bastante ilustrativa do ambiente cultural no qual se insere a obra Retórica nova (1301) de Ramon Llull, bastante distinto dos predecessores. Agora, no início do século XIV, estamos em um tempo de grande efervescência cultural, de expansão europeia - demográfica, especialmente - de enfrentamento com o Islá (apesar do fim das cruzadas na Terra Santa) e de intensos debates acadêmicos nas universidades. Enfim, estamos em um mundo bem mais complexo que o do Mediterrâneo romano da Antiguidade, ou mesmo do da Europa do início da Idade Média. Como a retórica foi pensada pelo filósofo?

Já tive a oportunidade de debruçar-me sobre a Retórica nova em duas ocasiôes, ambas com o conceito estético de beleza como alicerce de minhas consideraçóes. Trata-se de uma obra com muitas possibilidades de estudo, 
como já demonstraram os estudiosos Josep Batalla, Lluís Cabré e Marcel Ortín em sua "Introdução" para a edição da Obrador Edèndum em 20064 .

Por isso, tratarei aqui apenas de um capítulo da Retórica nova, que trata da ordem (conceito, de resto, não só retórico, mas filosófico, e importantíssimo para a visão de mundo, tanto clássica quanto medieval).

Como em tudo o que diz respeito à filosofia, a ordem é originalmente uma noção platônica - estruturante do pensamento, da alma, do mundo (tese especialmente exposta no Timeu). Naturalmente, a Idade Média herdou essa noção transcendental do conceito de ordem. Seu primeiro transmissor foi Santo Agostinho, que inclusive dedicou uma obra ao tema (De ordine): a ordem está expressa na beleza do universo, abrange tudo e nos eleva a Deus, que tudo criou e estabeleceu com uma determinada ordem (SAN AGUSTÍN, El orden).

Pseudo-Dionísio, o Areopagita (séc. V), talvez mais do que Agostinho, legou à Idade Média a ordem como uma ideia própria da constituição do universo: para ele, a criaçáo foi ordenada em uma hierarquia celeste e, em seguida, eclesiástica, distribuída em sucessivos graus trinos: "Todo bom dom e toda dádiva perfeita vem de cima e descende do Pai das luzes [...] As ordens e graus daqui de baixo simbolizam as harmoniosas relações do Reino de Deus." (PSEUDO-DIONÍSIO, A hierarquia celeste, I, 1 e 3, grifo nosso).

O pensamento cristão incorporou a ordem em todas as suas consideraçôes da vida, da sociedade, da cultura, da educação, como podemos ver em dois breves exemplos [de Gregório VII (1020-1085) e Pedro Lombardo (1095-1160)]:

A providência da administração divina instaurou graus e ordens distintas a fim de que, os inferiores, ao manifestarem respeito pelos superiores [potiores], e os superiores, ao exprimir afeição pelos inferiores, façam com que da diversidade nasça a concórdia e todos os oficios se organizem em uma composição harmônica. Esse conjunto só subsiste pela ordenação das diferenças. O exemplo das milícias celestes nos ensina que uma criatura náo pode viver nem ser governada na igualdade. Por acaso não sabem que anjos e arcanjos não são iguais, mas diferentes segundo seu poder e sua ordem? Se tal distinçâo existe entre eles, que são sem pecados, como os homens não seriam submetidos a uma disposição similar? (GREGÓRIO VII, Carta VI, 35, grifo nosso).

\footnotetext{
${ }^{4}$ BATALLA, J.; CABRÉ, L.; ORTÍN, M. Introducció a la Retòrica nova. In: RAMON L. Retòrica nova. (Ed. a cura de Josep Batalla, Lluis Cabré i Marcel Ortín). Turnhout; Santa Coloma de Queralt: Brepols; Obrador Edèndum, 2006. p. 35-90.
} 
Ordem é um sinal, algo sagrado através do qual a função e o poder espiritual são transmitidos àquele que é ordenado. Assim, se chama ordem ou grau a característica espiritual na qual se realiza a promoção do poder. (PEDRO LOMBARDO, Sentenças, IV, 24, 13, grifo nosso).

Apesar de não ter tido a formação acadêmica (universitária) já disponível em seu tempo, o do século XIII, o filósofo Ramon Llull conhecia a tradiçáo escolar retórica e estava em sintonia com os textos de sua época. Por exemplo, seu título "nova" (Retórica nova) já era utilizado há algum tempo - o exemplo mais conhecido é a obra Poesia nova (c. 1210) de Geoffroy de Vinsauf, representante de um movimento gramático denominado pelos especialistas de gramática preceptiva, cujos integrantes ensinavam elementos retóricos, além de preceitos gramaticais. No caso de Llull, sua retórica estava subordinada à estrutura de sua filosofia (a ars): sua intenção era servir de ferramenta interpretativa a todos os ramos do conhecimento. Por isso, seu texto sobre a retórica tinha a intenção de ser estudado como material apologético - para pregação cristã (o que o insere na tradição agostiniana, como vimos).

Seu conceito de ordem é bastante claro: a ordem é uma escolha de palavras de acordo com sua beleza. Elas devem estar relacionadas entre si para produzir uma beleza ainda maior, uma ornamentação, pois estáo a serviço da verdade do que representam gramaticalmente, e da verdade das verdades, a cristã. A retórica é uma arte da persuasão, pois move os ouvintes pelo prazer que provoca com a ordenação daquelas determinadas palavras. Ordem é aquilo que proporciona virtude e eficácia a um texto, a um discurso, pois faz com que as palavras ditas signifiquem exatamente o que querem dizer e convençam não só pela sua beleza, mas por sua verdade.

Aristotelicamente, Llull divide a ordem em três aspectos: forma, matéria e fim, com um duplo significado para cada um deles: 1) forma: 1a) essencial e 1b) acidental; 2) matéria: 2a) essencial e 2b) acidental; 3) fim: 3a) palavra comunicativa e 3b) palavra persuasiva. Na ordem das palavras - quais devem estar no princípio, quais no meio e quais no fim - Llull é mais "literário", e oferece três pequenas e interessantíssimas histórias (na terminologia medieval, exemplos-exempla): 1) com as palavras "rainha" e "serva"; 2) a história de uma petição que um cavaleiro fez a um rei (e ali insere um conto sobre Alexandre, $o$ Grande que retira de uma obra de Sêneca) e 3) um caso de adultério. 
Ofereço como apêndice desse trabalho a minha tradução do início da Retórica nova (com o primeiro capítulo, sobre a ordem), a primeira para o português, para que o leitor sinta o sabor de ler um texto escrito há mais de setecentos anos, e também para que faça o que já chamei de uma viagem ao cemitério, isto é, um exercício compreensivo de transposição temporal.

Explico. O trabalho de um pesquisador medievalista como eu é o de "traduzir" - isto é, explicar - para seus contemporâneos a linguagem e o conteúdo dos textos antigos. Isso é muito importante, especialmente para a aferição do que é explicado. Para isso, ideal é que o investigador do passado faça um pequeno exercício de tradução, talvez o ato mental mais intenso de todos, pois nos obriga a pensar cada palavra, a pô-las em nossa língua e a fazer adaptaçôes, na medida do possível, que não maculem as ideias originais daquele determinado escritor. É o que eu chamo de "tradução literal" (com aspas porque nunca haverá uma literalidade, já que estamos submersos em nosso próprio tempo).

De qualquer modo, é muito importante que, após isso, o leitor tenha a possibilidade de fazer uma leitura daquele texto traduzido. Ainda que não seja uma experiência textual direta, ele pode ter um gosto do tempo e saborear palavras, mesmo que adaptadas, de outra época, de outra mentalidade, do "outro" em sua máxima significação.

A Retórica nova é uma bela peça para encerrar meu périplo sobre o tema. Espero que apreciem a tradução do capítulo I.

\section{Conclusấo}

Chegamos ao fim de nossa jornada. Iniciamos com a mitologia grega, terminamos com um tratado de retórica escrito no início do século XIV por um filósofo catalão. Poderia avançar ainda mais - de fato, o humanismo ressaltou a importância da retórica, que só começou seu lento declínio com o racionalismo de Descartes (1596-1650) até chegar a seu ocaso e quase desaparecimento no século XIX (só a partir da segunda metade do XX ela voltou a ser novamente considerada). Mas sua história clássica e seu desdobramento medieval são mais que suficientes para o nosso objetivo (o resgate de nossas belíssimas tradiçóes culturais e da história de nossa cultura, a ocidental, greco-romana e judaico-cristã). Como afirmou Cícero, é a retórica que nos torna seres humanos completos! 
Toda a tradição literária e filosófica da história da retórica ressaltou sua importância para a formação plena do ser humano, sempre com a valorização dos princípios morais inerentes à boa educação. Sem ética não é possível educar ninguém: a educação pressupóe valores morais! Além disso, a retórica foi, desde seus primórdios, uma atividade intelectual transversal por excelência. Aliás, todo o sistema educacional clássico-medieval baseado nas artes liberais - gramática, dialética, retórica (trivium) e aritmética, geometria, música, astronomia (quadrivium) - estava fundamentado na transversalidade (sincrônica e diacrônica) e no vivo diálogo entre as disciplinas (o que hoje chamamos de interdisciplinaridade). Ainda que seu uso e função tenham variado conforme as épocas e intençóes de seus autores, como vimos, sua existência como segunda arte a ser aprendida pelo estudante (após a gramática) foi mantida com a ideia de que sua ornamentação enaltecia o valor real que cada palavra ordenada representava ao ouvinte. Só com a verdade as palavras podem ser decoradas pela retórica. Esse é o núcleo que dignifica e enaltece toda a sua história. Foi o que aqui tentamos demonstrar. 


\title{
ApÊNDICE \\ RETóRICA NOVA (1301), PRÓlOGO - PARTE 1
}

\author{
Ramon Llull (1232-1316)
}

Traduçáo e notas de Ricardo da Costa ${ }^{5}$.

\section{Prólogo}

Deus, em Vossa virtude começa a Retórica nova.

1. Como a palavra é o meio e o instrumento através do qual os loquazes e os ouvintes convêm em um único fim, consequentemente, quanto mais bem ordenadas e ornadas elas forem, mais plenas serão de beleza ${ }^{6}$; e quanto mais belas forem, mais prazerosas se tornarão aos ouvintes. Além disso, quanto mais prazerosas forem as palavras, mais necessário será que, graças a elas, unanimemente os loquazes e os ouvintes se unam em um fim. E como a arte retórica se ordena a este propósito, seu objeto será, portanto, a palavra ordenada, ornada e bela.

Há tempos desejávamos transmitir um ensinamento sobre a maneira de ordenar e ornar as palavras, e como compor sermóes conforme a Arte geral, mas iniludíveis obrigaçóes nos impediram ${ }^{7}$, sobretudo o fato de os loquazes exigirem um tratamento extenso, já que versam sobre diversos temas. Por isso, redigimos este livro em forma de compêndio, para trilhar um caminho fácil e útil para compor e redigir sermóes que, belos e naturais, versem sobre múltiplas e diversas matérias, sempre respeitando o desenvolvimento e a ordem devida.

5 Tradução feita a partir da edição RAMON LLULL. Retòrica nova (edició a cura de Josep Batalla, Lluís Cabré i Marcel Ortín). Turnholt/Santa Coloma de Queralt: Brepols/Obrador Edèndum, 2006 (ediçáo bilíngue latim/catalão). Revisão de Nayhara Sepulcri (CNPq-UFES). Aproveitamos também as eruditas notas explicativas desta edição, mas acrescentamos outras. ${ }^{6}$ A beleza intrínseca da palavra (verbo) tem sua origem em Deus: "No princípio era o Verbo, e o Verbo estava com Deus, e o Verbo era Deus." (Jo 1,1). As relaçôes entre Deus-Pai e Deus-Filho são explicadas por João através da palavra personificada de Deus. Portanto, quanto mais ordenadas forem as palavras graças à retórica, melhor representarão a relaçáo entre o Pai e o Filho.

${ }^{7} \mathrm{Na}$ lógica medieval, um sermão era o enunciado de um juízo ou uma ideia. 


\section{DA DIVISÁo DESTE LIVRo}

2. Para que a doutrina desse livro seja clara aos leitores, o dividimos em partes, e evidenciamos sua ordem para facilitar sua investigação. Assim, ele é formado por quatro partes: ordem, beleza, ciência e caridade.

3. A ordem é especialmente uma parte dessa ciência, já que com ela são transmitidos aos que advogam por uma causa a doutrina que ensina a observar a ordem devida em qualquer tipo de sermáo, os usos da palavra, para assim evitar a desordem. O objetivo é que, entre loquazes e ouvintes, se estabeleça aquela paz e amizade mútuas que nascem das palavras ordenadas e belas, tal como testemunha Sêneca, quando diz que "falar bem deve ser o princípio da amizade" 8 .

4. De modo semelhante, se diz que a beleza é uma parte da matéria dessa arte, porque consideram que ela é matéria da própria retórica. A beleza deve permitir a transmissão de uma doutrina por meio da qual todos possam ornar e decorar ${ }^{9}$ suas palavras com uma adequada congruência ${ }^{10}$.

5. A ciência é também uma parte de nossa retórica, pois transmite a doutrina que sugerimos aos leitores, supondo que a dominem e dela se sirvam para buscar o esplendor e o ornamento das palavras, além de como descobrir as palavras ornadas e belas. Dessa maneira, poderão discernir as palavras ordenadas e belas das desordenadas e torpes, e utilizar as belas e evitar as torpes $^{11}$.

6. A caridade é a quarta parte dessa arte, porque é dela que retiramos a doutrina, com ou sem palavras, pois as palavras surgidas da caridade refulgem esplendorosamente belas, de modo que, em última instância, sem a caridade elas não podem ser belas.

\footnotetext{
${ }^{8} \mathrm{Na}$ verdade, essa sentença, tradicionalmente atribuída a Sêneca (4 a.C. - 65 d.C.) e frequentemente citada pelos moralistas medievais, é originária de uma antologia anônima do séc. II.

9 No original decore (de decor - o que convém, o que tem graça, encanto, formosura, beleza corporal, ornamento, enfeite; por sua vez, de decus - beleza moral, virtude). Segundo Cícero (106-43 a. C.) (De officis, 1.96), "aquilo que é concorde com a natureza, em que aparecem a medida e a temperança com certo esplendor de nobreza". Esse conceito faz com que a retórica seja submetida à natureza, isto é, à razão e, assim, faz com que a palavra retórica realce a beleza inerente à coisa que ela alude.

${ }^{10}$ Congruência: harmonia duma coisa com o fim a que se destina; coerência.

${ }^{11}$ Ao utilizar o adjetivo torpe (desonesto, infame, abjeto, repugnante, obsceno), Llull chama a atenção para a face moral da retórica, exatamente como faz Aristóteles em sua obra Retórica.
} 


\section{DA PRIMEIRA PARTE DESSE LIVRO, DA ORDEM}

7. A ordem que se observa nas palavras é o que confere virtude e eficácia, tanto no loquaz quanto no ouvinte.

8. Esta ordem das palavras contém uma tríade que a configura: a forma, a matéria e o fim $^{12}$. Todas as três têm um duplo significado.

\section{A Forma DAS PALAVRaS}

9. A forma das palavras é dupla. A palavra tem uma forma essencial e própria que vem de si, e outra forma que lhe vem da adjunçáo de outra palavra: esta forma lhe é acidental.

Podemos dar um exemplo. A palavra "rainha" tem, por si mesma, uma grande beleza e uma grande ornamentação, que são sua forma essencial ${ }^{13}$. Mas há outra forma acidental, que surge quando acrescentamos uma palavra que signifique bondade. A bondade orna com mais graça e esplendor o que a palavra "rainha" significa, como quando dizemos "a rainha tem uma grande bondade", ou "a rainha é boa".

A razão pela qual dizemos isso é óbvia, já que a beleza significada pela palavra "rainha" concorda maximamente com a bondade. E a bondade, que é a forma acidental, decora e embeleza a beleza da rainha, que é forma essencial. Isso se manifesta sensivelmente em seu contrário, pois quando alguém diz "a rainha que tem uma grande beleza tem uma grande malícia”, vemos claramente que a malícia leva, aniquila e deturpa a forma essencial primária.

Aqui devemos expor a doutrina que permite discernir as duas formas das palavras, para que elas realcem o esplendor da própria forma essencial pela beleza da forma acidental, e possam evitar fazer o contrário, isto é, aniquilá-la. Assim, não fala retoricamente quem diz "a rainha tem uma grande beleza e uma grande malícia", ou "tem uma grande bondade e uma grande estultícia”. Dever-se-á emitir um juízo similar em tudo o que seja semelhante a isso.

\footnotetext{
12 A contraposição dos conceitos aristotélicos de matéria e forma era muito utilizada pelos gramáticos modistas de então.

13 As palavras são essencialmente belas ou feias na medida em que seu significado reflete a nobreza ou vileza da ordem. Llull aplica a ontologia inerente à lógica modista - que pressupunham que os diversos modos da palavra refletiam os modos de ser das coisas - à sua visão hierárquica da realidade. Em termos linguísticos, os modistas atribuíam aos nomes uma suppositio naturalis [segundo Pedro Hispano (Papa João XXI, 1210-1277)], acepção que fazia com que um termo comum se referisse, por sua natureza, a todas as coisas partícipes dele (Tratactus, 6.4).
} 


\section{A matéria das palaVras}

10. Assim como há uma dupla forma nas palavras, também há uma dupla matéria.

Uma, essencial e própria, é aquela que indica as dicçôes ou vocábulos, como "rainha", "grandeza", e "beleza”, já que as dicções e os vocábulos são a matéria e o substrato da forma das palavras ${ }^{14}$. Designam esta forma quando dizem "a rainha tem uma grande beleza". Estes vocábulos são a própria matéria da forma nas palavras, tal como as travas da quina do barco são a matéria da forma do barco.

Contudo, há outra matéria acidental nas palavras que mostra vocábulos como "rainha", "grandeza", "bondade". Estes vocábulos são matéria acidental da seguinte forma: "a rainha tem uma grande bondade". Assim como a forma "a rainha tem uma grande beleza" colore e embeleza a forma "a rainha tem uma grande beleza”, concluímos o que dissemos acima: também os vocábulos "rainha" e "beleza" são a matéria própria e primeira em relação às dicçóes "rainha" e "bondade"; que são sua matéria acidental, se ambas as matérias se referem à forma citada, a que propriamente lhe convém.

\section{A finalidade Das PalaVras}

11. Similarmente, a finalidade das palavras é dupla: uma é explicar, a outra, aquilo que o falante pretende com o que fala.

A primeira finalidade das palavras surge quando se explica ou se exprime algo, como quando alguém diz "a rainha que tem uma grande beleza, tem uma grande bondade".

A segunda finalidade das palavras é aquilo que quem fala tenta alcançar com o que diz, aquilo pelo qual ele pronuncia as palavras que diz. Esta finalidade é o complemento da locução e a perfeição das palavras, tal como seguinte exemplo: imaginemos que uma donzela diz a uma rainha "senhora, vós tendes uma grande beleza e uma grande bondade", com a intenção que

\footnotetext{
${ }^{14}$ Uma dicçáo é o signo oral que significa uma palavra. Ver Thomas d'Erfurt (séc. XIII) (Grammatica speculativa, 6.11: “dicçâo é voz significativa”) e Llibre de contemplació, 3.155.19 (OE II, p. 448): "Ah, Jesus Cristo, Senhor muito virtuoso e muito glorioso! O homem escreve a palavra em dicçóes para rapidamente entender os significados que as palavras demonstram. Assim, por isso, Senhor, a palavra é o objeto com o qual o entendimento pode ter as coisas significadas por elas."
} 
a senhora lhe proporcione um marido, pois esta era a finalidade pela qual a donzela se dirigia à senhora.

12. Estas três coisas - a forma, a matéria e o fim - fazem a ordenação das palavras. De tal maneira a ordem das palavras depende disso, que, sem as três, as palavras não podem ser devidamente ordenadas. Com isso em conta é que, na segunda e na terceira parte deste opúsculo, propomos investigar a ordem das palavras e as palavras ordenadas.

\section{A ordenaÇấo das palaVras}

13. Há outro modo de ordenar as palavras e que atende o princípio que estabelece naturalmente quais palavras devem ser colocadas no início, quais no meio e quais no $\mathrm{fim}^{15}$. Isso porque cada palavra não é indiferente à ordem que lhe corresponde em relação à outra.

Por exemplo: se alguém tivesse que falar de uma rainha e de uma escrava, deveria antepor a rainha à escrava, e dizer "a rainha e a serva têm uma grande beleza", e não "a serva e a rainha são ornadas por uma grande beleza”. É claro que o vocábulo "senhora", ou "rainha", é mais esplendoroso e nobre que "escrava", pois o vocábulo "senhora" ou "rainha" significa dignidade e domínio.

Por outro lado, a palavra "escrava" indica servidão e sujeição. Portanto, antepomos o nome "rainha" ao nome "escrava", pois aquilo que é mais digno deve ser anteposto àquilo que é indigno.

14. Esta ordem também deve ser respeitada nas petições, nas acusações, nas escusaçóes, e quando aconselhamos ${ }^{16}$.

15. Em primeiro lugar, devemos observar esta ordem nas petições, pois assim mais facilmente obteremos o que pedirmos. Deve fazer isso àquele que pede alguma coisa a alguém. Por exemplo, imaginemos que um cavaleiro

15 "Outro triângulo é de princípio, meio e fim, e nele entra tudo o que existe, pois o que existe ou existe no princípio, ou no meio, ou no fim, e nada pode ser encontrado fora desses princípios.” (RAMON LLULL, Arte breve, 2.2.2).

${ }^{16}$ A distinção entre petição, acusaçãolescusação e conselho tem certa correspondência com os tipos de discurso retórico ciceroniano (demonstrativo, deliberativo e judicial; CÍCERO, De inventione, 1.5). Llull pode-se ter baseado em Guilherme de Conches (1080-1145) (Moralium dogma philosophorum, I.B.2a), adaptação cristã do De officis de Cícero, onde, ao tratar da beneficência, afirma que pode ser feita "dando conselho" com "acusações e defesas". 
pobre $^{17}$ deseje pedir ao rei a concessão de um tributo a uma filha sua que esteja núbil para desfrutar um dote matrimonial ${ }^{18}$. Quem deseje fazer essa petição deve começar louvando o rei e elogiando-o, e inserir exemplos de doaçôes e de largueza para incitar a alma do rei a dar. Por exemplo, lhe cairia muito bem narrar a resposta dada certa vez por Alexandre ${ }^{19}$. Um militar régio, que durante muito tempo havia servido sob as ordens de Alexandre, pediu para ser provido com qualquer coisa que lhe permitisse viver honrosamente, porque seu corpo, por causa da idade, já náo estava mais apto para a milícia. O rei Alexandre deu-lhe uma cidade, mas o militar disse que não merecia receber tanto. Contam que o rei respondeu ao militar que não considerava do que ele era digno, mas qual prodigalidade encarnava a munificência real.

$\mathrm{O}$ rei demonstrou assim que preferia retribuir conforme o modo e a natureza próprios da largueza, náo segundo o modo da avareza e da pobreza, pois a pobreza do militar, do vassalo ou o serviço dispensado ao rei - e requerido pela dignidade real - exigiam que ele fosse recompensado com uma grande doação.

Em segundo lugar, uma vez dito o que é pertinente ao elogio da majestade real e de sua munificência e largueza, o suplicante deve apresentar a própria necessidade ou a da pessoa pela qual implora. Em nosso caso, a indigência e a fraqueza de sua filha mostram que ela não dispunha de nada para casar, e demonstra como seria vergonhoso e desonroso se não pudesse encontrar um marido.

Em terceiro lugar, ditas todas estas coisas, deve-se acrescentar o que sua petiçáo substancialmente pede, isto é, que o rei se digne a favorecer casamento de sua filha, adicionando, ainda, como conclusão, que este casamento contribuiria para enaltecer a honra da excelência real, e faria com que sua boa e louvável fama se estendesse aos seus súditos e vassalos, o que seria uma honra e um bem não desprezível para o próprio cavaleiro suplicante.

\footnotetext{
${ }^{17}$ Em latim, miles pauper. Para o tema, ver COSTA, R. "A cavalaria perfeita e as virtudes do bom cavaleiro no Livro da Ordem de Cavalaria (1275), de Ramon Llull”. In: FIDORA, A.; HIGUERA, J. G. (eds.) Ramon Llull caballero de la fe. Cuadernos de Anuário Filosófico. Série de Pensamiento Español. Pamplona: Universidad de Navarra, 2001. p. 13-40.

${ }^{18}$ Em latim, toro maritali gaudere (em latim clássico significava leito nupcial, mas no latim medieval poderia também significar dote matrimonial).

${ }^{19}$ Essa anedota é reportada por Sêneca (De beneficiis, 2.16) e era muito popular tanto na Antiguidade quanto na Idade Média.
} 
16. Os acusadores devem observar um modo semelhante na ordenação de suas palavras.

Quando alguém deseja acusar outra pessoa de alguma falta, após algumas palavras iniciais condenatórias da falta e do pecado, deve-se narrar a falta e, ao fim, acrescentá-la à posição que ocupa. Assim o fez, segundo dizem, certo cavaleiro que acusava seu senhor de tê-lo traído. O cavaleiro havia confiado sua mulher ao senhor, e este havia cometido adultério com ela. Em consequência, ao culpar seu senhor de traição, o mencionado cavaleiro iniciou sua narrativa com o que agravava o pecado de traição e o que fazia esta traição mais perniciosa entre os domésticos que confiavam em seus senhores.

Após dizer isso, ele deve acrescentar o modo como o senhor o traiu, isto é, como o senhor o desonrou com uma união adúltera com a senhora que lhe fora recomendada. Deve seguir previamente essa ordem bem traçada, prosseguir e, em forma de conclusão, expressar de modo veemente sua ira e indignação contra o senhor que, com tanta ingratidão, o tratou, e que, como se tornaram inimigos, ele poderia - e seria justo se o fizesse - recusar-lhe a obediência e a fidelidade que lhe devia como cavaleiro, já que o havia traído com um crime tão atroz.

17. Tampouco se deve separar o que é desculpável diante de alguém na ordenação das palavras. Primeiro, deve-se atentar como se podem harmonizar os elogios e os louvores diante daquele que se propóe perdoar. Em seguida, próximo da metade de suas palavras, deve denunciar o engano e a falta incorridos. Finalmente, deve apresentar uma boa desculpa, e dizer que, daí em diante, por nada no mundo tornará a cometer o engano ou a falta da qual foi acusado.

18. Quem aconselha outro, quando lhe dá o conselho, deve decorar suas palavras da seguinte maneira: primeiro, deve narrar ordenadamente todas as coisas que deseja aconselhar, para assim fazer ver claramente por onde terá que começar e como pensa que poderá obter o fim desejado. Na proposta, deve ficar muito clara a ordem sugerida: o que deve colocar no princípio, o que no meio, e o que no fim, para decidir o que colocar no que pediu conselho.

Assim, o intelecto e a imaginação de quem pede conselho capta com mais diligência e perspicácia enquanto empreende, continua e termina o que deve fazer para resolver o assunto. Quem escuta e entende dessa maneira as 
palavras de quem aconselha lhe parecem ornadas e lhe resultam prazerosas por causa de seu ornato e de sua beleza ${ }^{20}$.

19. Muitos outros modos poderíamos narrar em que as palavras se tornam ornadas e belas por causa da ordem que brota quando as colocamos esmeradamente no princípio, no meio e no fim. Não obstante, a ordem própria às palavras, convenientemente dispostas no lugar que lhes correspondem, provém da ordem e da forma, da matéria e do fim, tal como explicamos acima.

Assim entendemos o que deve ser colocado no princípio, no meio e no fim.

COSTA, R. Rhetoric in Antiquity and Middle Ages. Trans/Form/Ação, Marília, v. 42, p. 353-390, 2019. Edição Especial.

ABSTRACT: This article deals with rhetoric in Antiquity and Middle Ages from the perspective of eleven philosophers: Plato, Aristotle, Cicero, Seneca, Quintilian, the unknown author of the Rhetorica ad Herennium, Saint Augustine, Martianus Capella, Isidore of Seville, Bernard of Clairvaux, and Ramon It also offers an extract translated by us from Llull's Retorica nova (1301).

KEYwORDs: Rhetoric. Classical philosophy. Medieval philosophy. Speech.

\section{REFERÊNCIAS}

ARENDT, H. O conceito de amor em Santo Agostinho: ensaio de interpretação filosófica. Lisboa: Instituto Piaget, 1997.

ARISTÓTELES. Metafisica: ensaio introdutório, texto grego com tradução e comentário de Giovanni Reale. São Paulo: Ediçóes Loyola, 2005. 3 V.

ARISTÓTELES. Retórica. Prefácio e introdução: Manuel Alexandre Júnior. Tradução e notas: Manuel Alexandre Júnior, Paulo Farmhouse Alberto e Abel do Nascimento Pena. Lisboa: Centro de Filosofia da Universidade de Lisboa; Imprensa Nacional; Casa da Moeda, 2005a.

${ }^{20}$ A retórica proporciona prazer intelectual porque as palavras belas facilitam a compreensão. Por exemplo, no "prólogo" da Árvore exemplifical, Llull enaltece os exemplos porque através deles "pode-se ter um hábito universal para entender-se muitas coisas prazerosas de entender e prazerosas de ouvir". Ver RAMON LLULL. Árvore da ciência. Da árvore exemplifical (c. 1295-1296) (trad. e notas de Felipe Dias de Souza e Ricardo da Costa). Alicante: IVITRA, 2010. Disponível em: <http://www.ivitra.ua.es/ RicardoCosta/Arbor(Ed).pdf> 
AYMARD, A.; AUBOYER, J. Roma e seu Império: história geral das civilizaçôes. São Paulo: Difusão Europeia do Livro, 1958. T. II.

BROWN, P. “Antiguidade tardia”. In: ARIÈS, P.; DUBY, G. (dir.). História da vida privada I: do Império Romano ao ano mil. São Paulo: Companhia das Letras, 1990. p. 224-299.

CAPELA, M. M. F. Libro V: La retórica. Traducción y notas de Pedro Rafael Díaz y Díaz. Florentia Iliberritana: Revista de Estudios de Antigüedad Clássica, n. 2, p. 117-160, 1991.

CAPELA, M. M. F. Las nupcias de Filología y Mercurio. Libros I-II: Las bodas místicas. Madrid: Consejo Superior de Investigaciones Científicas (CSIC), 2016.

CICERÓ. Bruto: de los oradores il.lustres. Edició de Bulmaro Reyes Coria. Mèxico: Universidad Nacional Autónoma de México, 2004.

CICERÓ. Discursos. Vol. X: Catilinàries . Traducció i introducció de Oliveri Nortes i Valls. Barcelona: Fundació Bernat Metge, 1974.

CÍCERO. Do orador: 1.122-159. Tradução: Adriano Scatolin. Nuntius Antiquus, Belo Horizonte, v. 12, n. 2, p. 264-287, 2016.

CICERÓN. El orador. Texto revisado y traducido por Antonio Tovar y Aurelio R. Bujaldón. Barcelona: Ediciones Alma Mater, S. A., 1992.

CONVENIT SELECTA - 7. Cicero and the Middle Ages. Disponível em: <http://www. hottopos.com/convenit7/sumar.htm> Acesso em: 20 jun. 2019.

COSTA, R. História e memória: a importância da preservação e da recordação do passado. In: LAUAND, J. (org.). SEMINÁRIO INTERNACIONAL CEMOROC. 8. 2008. Filosofia e Educação: Estudos... São Paulo: Editora SEMOrOc da Faculdade de Educação da USP; Factash Editora, 2008. p. 81-89. Disponível em: <https://www.ricardocosta. com/artigo/historia-e-memoria-importancia-da-preservacao-e-da-recordacao-do-passado $>$ Acesso em: 20 jun. 2019.

COSTA, R. La Retórica nova (1301): la belleza a servicio de la conversión. eHumanistal IVITRA, v. 8, p. 28-43, 2015. (A. Monogràfic I. Arts of Finding Truth: Approaching Ramon Llull, 700 Years Later). Disponível em: <http://www.ehumanista.ucsb.edu/sites/secure.lsit. ucsb.edu.span.d7_eh/files/sitefiles/ivitra/volume8/1.monograficI/3_Costa.pdf> Acesso em: 19 jun. 2019.

COSTA, R. A educação na Idade Média: a Retórica nova (1301) de Ramon Llull. Revista NOTANDUM, Universidade do Porto, Porto: Editora Mandruvá, Ano XI, n. 16, p. 2938, 2008. Disponível em: <http://www.hottopos.com/notand16/ricardo.pdf> Acesso em: 20 jun. 2019.

JAEGER, W. Paidéia: a formação do homem grego. São Paulo: Martins Fontes, 1989.

MITRE FERNÁNDEZ, E. Sociedad y cultura cristianas en el Occidente Altomedieval. In: Historia del Cristianismo, II, El mundo medieval. Madrid: Ed. Trotta, 2004. p. 97-118. 
NOUGUÉ, C. Suma gramatical da língua portuguesa: gramática geral e aplicada. São Paulo: É Realizações, 2015.

PLATÃO. A República. Tradução e notas: Maria Helena da Rocha Pereira. Lisboa: Fundação Calouste Gulbenkian, 1996.

PLATÃO. Diálogos. Protágoras - Górgias - Fedão. Tradução do grego: Carlos Alberto Nunes. Belém: Editora da UFPA, 2002.

PLATÃO. Diálogos. Timeu - Crítias - O Segundo Alcibiades - Hipias Menor. Tradução direta do grego: Carlos Alberto Nunes. Belém: EDUFPA, 2001.

PLATÃO. Fedro. Introdução, tradução e notas: José Ribeiro Ferreira. Lisboa: Edições 70, 2009.

QUINTILIANO. Instituição oratória. Tradução, apresentção e notas: Bruno Fregni Basseto. Campinas: Editora da Unicamp, 2015-2016. 4 v.

RAMON LLULL. Retòrica nova. Ed. a cura de Josep Batalla, Lluis Cabré i Marcel Ortín. Turnhout; Santa Coloma de Queralt: Brepols; Obrador Edèndum, 2006.

SAN AGUSTÍN. El orden. In: Obras completas. Version Espanola. Disponível em: <http://www.augustinus.it/spagnolo/ordine/index.htm> Acesso em: 20 jun. 2019.

SAN ISIDORO DE SEVILLA. Etimologias. Madrid: BAC, MM, 2004. 2 v.

SANTO AGOSTINHO. A cidade de Deus. Tradução, prefácio, nota biográfica e transcrições: J. Dias Pereira. Lisboa: Fundação Calouste Gulbenkian, 2011. V. 3.

SANTO AGOSTINHO. A doutrina cristã: manual de exegese e formação cristã. Tradução: Ir. Nair de Assis Oliveira, csa. São Paulo: Paulus, 2002.

SÃO BERNARDO DE CLARAVAL. Carta de Bernardo a Roberto, seu sobrinho, que mudou da ordem cisterciense para a cluniacense. Tradução: Ricardo da Costa. Disponível em: <https://www.ricardocosta.com/traducoes/textos/carta-de-bernardo-roberto-a-seusobrinho> Acesso em: 15 jun. 2018.

SÉNECA, LÚCIO ANEU. Cartas a Lucílio. Tradução, prefácio. e notas: J. A. Segurado Campos. Lisboa: Fundação Calouste Gulbenkian, 2007.

VEYNE, P. Quando nosso mundo se tornou cristão [312-394]. Rio de Janeiro: Civilização Brasileira, 2010.

Recebido: 30/12/2019

Aceito: 30/12/2019 